B. I. Новошицька, доцент кафедри господарського права Донецького національного університету імені Василя Стуса, кандидат юридичних наук

\title{
ЩОДО ДОКАЗУВАННЯ ТА ДОКАЗІВ У СПОРАХ ПРО СТЯГНЕННЯ ЗБИТКІВ У СФЕРІ ГОСПОДАРЮВАННЯ
}

Ключові слова: докази, доказування, збитки у сфері господарювання, стягнення збитків, письмові докази, висновок експерта, речові докази.

Одним із способів захисту прав і законних інтересів учасників економічних відносин є відшкодування збитків у сфері господарювання, який, зазвичай, реалізується за допомогою юрисдикційної форми захисту на підставі поданого зацікавленою стороною позову про стягнення збитків до господарського суду. Швидке вирішення спору та отримання позивачем позитивного рішення передусім залежить від повноти використання засобів доказування, дослідження та оцінки судом наданих доказів.

Практика вказує на те, що вирішення господарським судом відповідного спору на користь особи, яка понесла збитки, у багатьох випадках виявляється неможливим саме через недоведеність позивачем наявності підстави та всіх умов, необхідних для відшкодування збитків, що суттєво впливає на застосування цієї форми відповідальності.

Положення щодо доказів і доказування, зокрема у спорах про стягнення збитків, містяться в Господарському процесуальному кодексі України (далі ГПКУ) [1]. Крім цього, на зазначені відносини поширюються окремі положення інших законів, зокрема Господарського кодексу України (далі - ГКУ) [2], Цивільного кодексу України (далі - ЦКУ) [3], підзаконних нормативно-правових актів, норми міжнародних договорів, що є частиною національного законодавства. Однак деякі з цих положень потребують конкретизації.

Окремі аспекти, пов'язані із доказуванням та доказами у спорах про стягнення збитків, зокрема у сфері господарювання, частково розглядали представники різних галузей юридичної науки, зокрема в останні роки, такі автори, як-от А. І. Гурова, Т. С. Ківалова, М. В. Краснова, Т. Є. Крисань, І. В. Подколзін, Т. Я. Рим, I. В. Розізнана, А. В. Янчук та інші, але комплексного дослідження у цьому напрямі не проводилося. 
Наведене вказує на актуальність теми цього дослідження, метою якого $\epsilon$ розробка та обтрунтування пропозицій щодо доказування та доказів у спорах про стягнення збитків у сфері господарювання.

Для досягнення зазначеної мети доцільним є розгляд питань щодо розподілу обов'язку стосовно доказування, а також належних доказів, якими повинні підтверджуватися вимоги про стягнення збитків, адже саме ці аспекти мають найбільші особливості щодо стягнення збитків, порівняно з іншими категоріями спорів.

Розподіл обов'язку доказування має значення ще на стадії підготовки позовної заяви. Від вирішення цього питання залежить те, на підтвердження яких фактів потрібно подавати докази позивачу, та які докази повинен буде представити у подальшому відповідач.

За загальними правилами судового процесу кожна сторона повинна довести обставини, які мають значення для справи і на які вона посилається як на підставу своїх вимог або заперечень, крім випадків, встановлених законом (ч. 3 ст. 13, ч. 1 ст. 74 ГПКУ).

Із приводу розподілу обов'язку щодо доказування Вищий арбітражний суд України у п. 6 Роз'яснення «Про деякі питання практики вирішення спорів пов’язаних з відшкодуванням шкоди» № 02-5/215 від 1 квітня 1994 р. зазначив, що для правильного вирішення таких спорів важливе значення має розподіл між сторонами обов'язку доказування, тобто визначення, які юридичні факти повинен довести позивач або відповідач. Встановлення причинного зв'язку між протиправною поведінкою особи, яка завдала шкоду, та збитками потерпілої сторони $\epsilon$ важливим елементом доказування наявності реальних збитків. Потрібно довести, що протиправна дія чи бездіяльність завдавача $є$ причиною, збитки, які виникли у потерпілої особи, - наслідком такої протиправної поведінки [4].

У науці господарського права відзначається, що для господарських відносин характерна презумпція винуватості порушника, з огляду на яку, не потерпіла сторона повинна доводити, що правопорушення було скоєно за наявності вини боржника, а несправний учасник господарських відносин, для запобігання застосування до нього господарських санкцій, несе тягар доказування того, що ним було застосовано всі залежні від нього заходи. Водночас, за загальним правилом, єдиною обставиною, що звільняє учасника господарських відносин від відповідальності за господарське правопорушення, є непереборна сила (що принципово відрізняє господарсько-правову відповідальність від цивільно-правової, в якій обставиною, що виключає відповідальність, є і випадок) [5, с. 686], що випливає 3 положення ч. 2 ст. 218 ГКУ.

Зазначене правило розповсюджується і на відносини щодо стягнення збитків у сфері господарювання, тому позивач не повинен доказувати наявність вини відповідача у заподіянні збитків та відповідно зазначати у позовній заяві докази, 
якими буде підтверджуватися вина відповідача у заподіянні збитків. Навпаки, на відповідача покладено тягар доказування того, що в його діях відсутня вина у заподіянні збитків. На зазначену особливість звертає увагу і заступник голови господарського суду Волинської області В. А. Войціховський, зазначаючи: якщо потерпілий довів наявність шкоди, то той, хто завдав їі, повинен довести протилежне - відсутність своєї вини [6].

Правила розподілу обов'язку щодо доказування вимагають від позивача, який вважає, що йому завдано збитків, додання до позовної заяви доказів вжиття заходів для їхнього запобігання (мінімізації), адже відповідно до ч. 3 ст. 226 ГКУ сторона господарського зобов'язання позбавляється права на відшкодування збитків у разі, якщо вона була своєчасно попереджена другою стороною про можливе невиконання нею зобов'язання і могла запобігти виникненню збитків своїми діями, але не зробила цього, крім випадків, якщо законом або договором не передбачено інше. Зі свого боку в подальшому відповідач зобов'язаний надати суду докази повідомлення ним позивача про порушення зобов'язання у разі посилання на невжиття другою стороною заходів щодо запобігання збиткам та заявлення вимоги щодо відповідного зменшення розміру збитків, що також випливає з приписів зазначеної норми.

Субсидіарно до цих відносин застосовується положення ч. 4 ст. 623 ЦКУ, тому, у разі заявлення вимог про стягнення втраченої вигоди, позивачу треба відразу зазначити докази вжиття заходів до ії одержання, адже останні враховуються при визначенні неодержаних доходів.

Отже, позивач при зверненні до господарського суду повинен зазначити, якими доказами підтверджується протиправність поведінки відповідача; розмір завданих збитків; наявність причинного зв'язку між протиправною поведінкою відповідача та збитками; вжиття заходів для запобігання (мінімізації) збитків та одержання втраченої вигоди. Зі свого боку відповідач несе тягар доказування відсутності своєї вини у порушенні господарського зобов'язання чи правил здійснення господарської діяльності та зобов'язаний надати суду докази повідомлення ним позивача про порушення зобов'язання у разі посилання на невжиття другою стороною заходів щуодо запобігання збиткам та заявлення вимоги щзодо відповідного зменшення розміру збитків.

Ще одним важливим питанням є те, якими саме доказами повинні підтверджуватися вимоги про стягнення збитків. Так, позивач у своїй позовній заяві повинен зазначити докази, що підтверджують обставини, якими він обгрунтовує свої вимоги (п. 5 ч. 3 ст. 162 ГПКУ). Повне та правильне відпрацювання відповідної частини позовної заяви набуває особливого значення, оскільки позивач повинен подати всі докази разом з поданням позовної заяви (ч. 2 ст. 80 ГПКУ). Вирішення спору про стягнення збитків на підставі зібраних у підготовчому прова- 
дженні матеріалів здійснюється в процесі розгляду справи по суті (ст. 194 ГПКУ). Ця стадія також $є$ важливою, адже тут здійснюється огляд, дослідження та оцінка наведених доказів, і саме через недоведеність відповідних фактів суди відмовляють у задоволенні вимог про стягнення збитків при прийнятті рішення.

Сторони подають тільки ті докази, які стосуються предмету доказування, під яким розуміються обставини, які підтверджують заявлені вимоги чи заперечення або мають інше значення для розгляду справи і підлягають встановленню при ухваленні судового рішення (ч. 2 ст. 76 ГПКУ).

Перелік доказів для підтвердження вимог про стягнення збитків залежить як від характеру правопорушення, так і від складової збитків, про стягнення якої проситиме позивач. Так, у разі завдання збитків від невиконання договору поставки види доказів будуть залежати від характеру завданих збитків: докази на підтвердження упущеної вигоди будуть зовсім іншими, ніж докази на підтвердження понесених додаткових витрат. Так само не можна визначити і єдиний перелік доказів на підтвердження додаткових витрат, здійснених внаслідок порушення договору поставки та договору перевезення вантажів, адже не зважаючи на необхідність доведення однієї і тієї ж складової збитків, тобто додаткових витрат, перелік доказів буде різним через те, що збитки завдані у різних відносинах. Можна погодитися з С. Л. Дегтяревим, що при визначенні необхідних доказів у цій категорії спорів можна говорити лише про деякі загальні рекомендації, головна із яких містить наступне: сторона при визначенні необхідних доказів повинна виходити із фактів, що підлягають встановленню у справах про стягнення збитків, тобто предмету доказування [7, с. 493].

3 урахуванням наведеного важливо окреслити коло доказів, на які сторони можуть посилатися для обгрунтування своїх вимог про стягнення збитків у сфері господарювання.

Доказами у справі $є$ будь-які дані, на підставі яких суд встановлює наявність або відсутність обставин (фактів), що обгрунтовують вимоги і заперечення учасників справи, та інших обставин, які мають значення для вирішення справи (ч. 1 ст. 73 ГПКУ). Ці дані встановлюються такими засобами: письмовими, речовими і електронними доказами; висновками експертів; показаннями свідків (ч. 2 ст. 73 ГПКУ).

Найбільш поширеним видом доказів, що підтверджують наявність збитків та інші обставини і факти, що підлягають встановленню, $є$ письмові докази, якими $є$ документи (крім електронних документів), які містять дані про обставини, що мають значення для правильного вирішення спору (ч. 1 ст. 91 ГПКУ).

Форма і зміст документів, які подаються до господарського суду, повинні відповідати вимогам, установленим чинним законодавством для цих документів. Наприклад, цивільне законодавство встановлює вимоги до форми правочину: 
письмова та нотаріально посвідчена. Платіжні документи мають відповідати вимогам, що встановлюються нормативними актами Нацбанку України. Документи бухгалтерської та податкової звітності оформляються згідно з вимогами відповідних нормативних актів тощо. Письмові докази подаються в оригіналі або належним чином засвідченій копії, якщо інше не передбачено ГПКУ; якщо для вирішення спору має значення лише частина документа, подається засвідчений витяг з нього (ч. 2 ст. 91 ГПКУ). На необхідність правильного засвідчення письмових доказів для того, щоб вони були належними і допустимими, звертає увагу і Д. Зятіна [8, с. 85]. На окремі проблеми засвідчення копій документів звертає увагу С. Теньков [9].

Кожна складова збитків підтверджується відповідними доказами. Для того, щоб до складу збитків при доказуванні у суді була врахована вартість втраченого, пошкодженого або знищеного майна, згідно з ч. 1 ст. 225 ГКУ, необхідно дотримуватися загального правила: вартість такого майна має бути визначена відповідно до вимог законодавства.

Першим важливим доказом при стягненні збитків у вигляді вартості пошкодженого, втраченого або знищеного майна є правовстановлюючий документ на таке майно, тобто документ, який підтверджує право суб'єкта на майно та складений у порядку, передбаченому законодавством. Таким документом може бути, наприклад, договір купівлі-продажу. Майно може знаходитися у володінні суб'єкта господарювання і на праві оренди, бути переданим у лізинг та ін. Крім цього, треба звернути увагу, що питання реєстрації відповідних прав врегульовано постановою КМУ від 25 грудня 2015 р. № 1127 «Про державну реєстрацію речових прав на нерухоме майно та їх обтяжень» [10].

Наступним доказом, що може застосовуватися при розгляді таких категорій спорів, є акт приймання-передачі майна, у якому зазначається вартість останнього. Акт приймання-передачі є важливим письмовим доказом ще й на тій підставі, що він засвідчує факт передачі та приймання майна суб’єктом господарювання. Водночас потребує уваги те, що багато господарських операцій припускають, що товарно-матеріальні цінності можуть передаватися без переходу права власності. Такі операції можуть стосуватися процедур ремонту, модернізації, зберігання та ін. Зазвичай, перелічені акти складаються у довільній формі, однак такий документ є первинним, тому повинен мати обов'язкові реквізити, для того щоб бути підставою для бухгалтерського обліку відповідної господарської операції (Лист Мінфіну від 13.06.2017 р. № 35210-07/23-2135/1/1902 «Вимоги щодо складання первинних документів» [11]). Крім цього, щодо установ і організацій, які утримуються за рахунок державного або місцевих бюджетів, такий документ, складений до 13 вересня 2016 р., повинен відповідати Інструкції зі складання типових форм з обліку та списання основних засобів, що належать установам і орга- 
нізаціям, які утримуються за рахунок державного або місцевих бюджетів, затвердженій наказом Державного комітету статистики України від 2 грудня 1997 p. № 125/70 (типова форма № 03-1, № 03-2 та ін.) [12]. Вимоги до складання акту приймання-передачі основних засобів передбачено і Порядком складання типових форм з обліку та списання основних засобів суб'єктами державного сектору, затвердженим Наказом Міністерства фінансів України від 13 вересня 2016 р. № 818 [13].

Для підтвердження вимог про стягнення збитків від втрати, пошкодження та знищення майна можуть бути використані також і матеріали інвентаризації, документи з бухгалтерського обліку, оцінки пошкодженого майна, що проводилася для, зокрема, його приватизації (корпоратизації), оренди, проєктно-кошторисна документація, документи бюро технічної інвентаризації на нерухоме майно, землевпорядна документація на земельну ділянку у разі повернення у державну власність об'єкта приватизації, що був проданий разом із земельною ділянкою, на якій він розташований, документи з відомостями про фізичний стан та технічні характеристики майна, фінансова звітність, матеріали аудиту, а також інші документи залежно від того, який саме факт підлягає доведенню. Такий висновок випливає з аналізу Методики оцінки майна (п. 84), затвердженої постановою КМУ від 10 грудня 2003 р. № 1891, яка зорієнтована на визначення розміру збитків, що призвели до завдання майнової шкоди державі, територіальній громаді або суб' єкту господарювання з державною часткою (часткою комунального майна) в статутному (складеному) капіталі, у разі встановлення фактів розкрадання, нестачі, знищення, псування майна (п. 81) [14].

Положення п. 87 вищеназваної Методики вказує на можливість надання звіту про оцінку збитків на підтвердження суми понесених збитків.

Як докази у спорах щодо стягнення збитків від втрати, пошкодження або знищення майна може бути подано звіт про оцінку майна (акт оцінки майна). Проведення оцінки майна є обов'язковим у випадках визначення збитків або розміру відшкодування у випадках, встановлених законом, що передбачено ст. 7 Закону України «Про оцінку майна, майнових прав та професійну оціночну діяльність в Україні» від 12 липня 2001 р. № 2658-III. Ч. 3 цієї ж статті встановлено, що проведення незалежної оцінки майна $є$ обов'язковим у випадках визначення збитків або розміру відшкодування, під час вирішення спорів та в інших випадках, визначених законодавством або за згодою сторін. Відповідно до ст. 12 вищеназваного Закону, звіт про оцінку майна є документом, що містить висновки про вартість майна та підтверджує виконані процедури з оцінки майна суб'єктом оціночної діяльності - суб'єктом господарювання відповідно до договору. Акт оцінки майна $є$ документом, що містить висновки про вартість майна та підтверджує виконані процедури з оцінки майна, здійсненої суб'єктом оціночної діяль- 
ності - органом державної влади або органом місцевого самоврядування самостійно. Якщо процедурами з оцінки майна для складання акту оцінки майна передбачене попереднє проведення оцінки майна повністю або частково суб'єктом оціночної діяльності - суб’ єктом господарювання, звіт про оцінку такого майна додається до акту оцінки майна [15].

Судова практика вказує на можливість представлення і таких доказів, як-от акт обстеження майна (на підтвердження факту пошкодження майна), складений представниками позивача та відповідача, договір та акт приймання-передачі послуг (у випадку усунення пошкоджень, завданих майну) [16] та ін.

Окрім письмових доказів на підтвердження збитків від втрати, знищення або пошкодження майна, як доказ може бути представлено і висновок експертизи. В цьому є потреба фактично в кожному випадку звернення суб'єкта господарювання до господарського суду, коли відсутня відповідна методика розрахунку розміру збитків, оскільки це суттєво збільшує ризик недоведення такого розміру.

Питання призначення і проведення судових експертиз врегульовано ст. 98-107 ГПКУ, Законом України «Про судову експертизу» [17], Інструкцією про призначення та проведення судових експертиз та експертних досліджень, затвердженою наказом Міністерства юстиції України від 8 жовтня 1998 р. № 53/5, з урахуванням Науково-методичних рекомендацій з питань підготовки та призначення судових експертиз та експертних досліджень, також затверджених згаданим наказом Міністерства юстиції України [18] та ін.

Д. Зятіна звертає увагу, що судова експертиза призначається лише у разі дійсної потреби у спеціальних знаннях, коли висновок експерта не можуть замінити інші засоби доказування, що необхідно враховувати учасникам справи у разі заявлення клопотань про призначення судової експертизи [8, с. 86].

Наприклад, у справах щодо стягнення збитків судом може бути призначено автотоварознавчу та транспортно-товарознавчу експертизи, до основних завдань яких належить визначення ринкової вартості колісних транспортних засобів, їхніх складових, а також розміру вартості матеріальних збитків, заподіяних власнику або володільцю колісних транспортних засобів, їхніх складових унаслідок пошкодження таких засобів, що випливає з п. 2.1. Р. 4 Науково-методичних рекомендацій з питань підготовки та призначення судових експертиз та експертних досліджень. Одним із головних завдань бухгалтерської експертизи є встановлення документальної обгрунтованості нестачі або надлишків товарно-матеріальних цінностей і грошових коштів, періоду і місця їхнього утворення, а також розміру заподіяної матеріальної шкоди, що випливає 3 п. 1 Р. 5 Довідника 3 підготовки матеріалів, що направляються на судову експертизу арбітражними судами, затвердженого наказом ВАСУ, Міністерства юстиції України від 14 липня 1998 р. № 11/40/5 [19]. 
Отже, визначення кола доказів у справах щодо стягнення збитків від втрати, пошкодження або знищення майна залежить від характеру самого правопорушення. Водночас, узагальнюючи відомі підходи та судову практику, можна запропонувати такий перелік доказів у иих справах: правовстановлюючий документ на відповідне майно; акт приймання-передачі майна, у якому зазначається його вартість; матеріали інвентаризаиіі; документи бухгалтерського обліку; проєктно-кошторисна документація; документи бюро технічної інвентаризаиії; землевпорядна документація; фінансова звітність; матеріали аудиту; акт оцінки майна; акт обстеження майна, складений представниками позивача та відповідача; договір та акт приймання-передачі робіт (у випадку усунення поикоджень); звіт про оцінку збитків; висновок експерта та інші докази.

При визначенні доказів, якими потрібно доводити вимоги та заперечення у справах про стягнення матеріальної компенсаиії моральної (немайнової) шкоди, заслуговують уваги положення постанови пленуму Верховного Суду України «Про судову практику в справах про відшкодування моральної (немайнової) шкоди» від 31 березня 1995 р. Так, у позовній заяві про відшкодування моральної (немайнової) шкоди має бути зазначено, в чому полягає ця шкода, якими неправомірними діями чи бездіяльністю їі заподіяно позивачеві, з яких міркувань він виходив, визначаючи розмір шкоди, та якими доказами це підтверджується. Суд, зокрема, повинен з'ясувати, чим підтверджується факт заподіяння позивачеві моральних чи фізичних страждань або втрат немайнового характеру, за яких обставин чи якими діями (бездіяльністю) вони заподіяні, в якій грошовій сумі чи в якій матеріальній формі позивач оцінює заподіяну йому шкоду та з чого він при цьому виходить, а також інші обставини, що мають значення для вирішення спору (п. 4, 5) [20].

Не зважаючи на спробу роз'яснити порядок застосування зазначеної форми відповідальності у постанові Верховного Суду України, позови про стягнення немайнової шкоди і сьогодні здебільшого залишаються судами без задоволення, прикладом чого може стати рішення господарського суду м. Києва від 25 листопада 2019 р. у справі №910/11361/19. Відмовляючи у задоволенні позову про стягнення з Товариства 3 обмеженою відповідальністю «Міжнародна інноваційна компанія нових технологій» відшкодування моральної шкоди у розмірі 50 000,00 грн на користь Товариства з обмеженою відповідальністю «Торгівельна столиця», суд зазначив, що позивачем не додано належних доказів на підтвердження викладених тверджень про заподіяння позивачу моральної шкоди та наявності втрат немайнового характеру, що настали з огляду на приниження його ділової репутації внаслідок дій відповідача, а також доказів наявності причиннонаслідкового зв'язку між такими обставинами та протиправними діями відповідача щодо розповсюдження недостовірної інформації [21]. 
Вирішальним для цієї категорії спорів є представлення суду доказів, що підтверджують зниження нематеріальних активів суб'єкта господарювання. Як приклад можна навести рішення господарського суду м. Києва від 11 грудня 2014 р. у справі № 910/18746/14, яким відмовлено у задоволенні позовних вимог про стягнення моральної шкоди, зокрема і через те, що позивачем не представлено доказів щодо зниження вартості нематеріальних активів [22]. Такого ж висновку дійшов господарський суд Рівненської області у рішенні від 3 липня 2012 р. у справі № 5019/372/12, зазначивши, що, оскільки позивачем не надано доказів зниження вартості його нематеріальних активів, ступеню зниження ділової репутації, а також не надано інших належних та допустимих доказів в підтвердження спричинення йому немайнової (моральної) шкоди, суд вважає недоведеним факт спричинення ТОВ «Ріф» втрат немайнового характеру (немайнової шкоди) [23].

Наведена практика набула поширення, і більшістю рішень господарських судів відмовляється у задоволенні вимог такого роду, що практично в кожному випадку обгрунтовується, між іншим, відсутністю у справі доказів, які б свідчили про зниження вартості нематеріальних активів суб'єктів господарювання.

Методологічні засади формування у бухгалтерському обліку інформації про нематеріальні активи і незавершені капітальні інвестиції в нематеріальні активи та розкриття інформації про них у фінансовій звітності в законодавстві можна знайти, зокрема, у Положенні (стандарті) бухгалтерського обліку 8 «Нематеріальні активи» [24] та Національному положенні (стандарті) бухгалтерського обліку в державному секторі 122 «Нематеріальні активи» [25].

Грошовий еквівалент ділової репутації може бути виражений у формі гудвілу. При цьому у разі відсутності у суб'єкта господарювання бухгалтерського обліку гудвілу як нематеріального активу такий суб'єкт господарювання не позбавлений права доводити розмір грошового еквіваленту приниження ділової репутації іншими доказами. У випадках виникнення з огляду на це питань, роз'яснення яких потребує спеціальних знань, господарський суд може призначити відповідну судову експертизу (п. 6 Інформаційного листа Вищого господарського суду України (далі - ВГСУ) № 01-8/184 від 28 березня 2007 р. «Про деякі питання практики застосування господарськими судами законодавства про інформацію») [26].

Отже, для стягнення моральної (немайнової) шкоди у сфері господарювання необхідно довести зниження вартості нематеріальних активів підприємства, на підтвердження чого можуть бути надані документи бухгалтерського обліку, а саме фінансова звітність, у якій зазначається вартість нематеріальних активів, а також висновок відповідної експертизи.

Одним із найскладніших питань, що виникають при вирішенні спорів про стягнення збитків, є питання підтвердження доказами наявності втраченої виго- 
ди, про стягнення якої заявляє позивач, тому зазначені проблеми стали предметом розгляду та узагальнення ВГСУ. Так, в Оглядовому листі від 14 січня 2014 р. № 01-06/20/20143 ВГСУ зазначив, що у вирішенні спорів про відшкодування збитків у вигляді упущеної вигоди суди повинні дослідити, чи могли такі збитки бути реально понесені кредитором та чи вживав кредитор заходів щодо їхнього відшкодування. У вигляді упущеної вигоди відшкодовуються тільки ті збитки, які б могли бути реально отримані. Пред'явлення вимоги про відшкодування неодержаних доходів (упущеної вигоди) покладає на кредитора обов'язок довести, що ці доходи (вигода) не є абстрактними, а дійсно були б ним отримані. Позивач повинен довести також, що він міг і повинен був отримати визначені доходи, $\mathrm{i}$ тільки неправомірні дії відповідача стали єдиною і достатньою причиною, яка позбавила його можливості отримати прибуток [27].

Складність доведення наявності втраченої вигоди призвела до того, що більшість вимог такого роду залишаються без задоволення (рішення господарського суду Житомирської області від 5 березня 2019 р. у справі № 906/452/18 [28], piшення господарського суду м. Києва від 28 травня 2019 р. у справі № 910/4238/19 та ін. [29]).

Отже, при заявленні вимог про стягнення втраченої вигоди позивач повинен представити суду докази, які б підтверджували, щуо такі доходи могли бути реально ним одержані.

Окрім згаданих письмових доказів та висновків експертів, при вирішенні спорів щодо стягнення збитків у сфері господарювання можуть застосовуватися також речові докази (ст. 93-95 ГПКУ), під якими розуміються предмети матеріального світу, які своїм існуванням, своїми якостями, властивостями, місцезнаходженням, іншими ознаками дають змогу встановити обставини, що мають значення для справи (ст. 93 ГПКУ). На відмінності між письмовими та речовими доказами звертає увагу В. Е. Беляневич, який стверджує, що, якщо інформація про факти міститься в документі, цей доказ є письмовим; якщо ж інформація про факти підтверджується властивостями документа як предмета, цей доказ є речовим [30, с. 497]. Водночас аналіз судової практики дає підстави стверджувати, що використання речових доказів у справах про стягнення збитків не набуло поширення.

Як і при вирішенні інших категорій справ, важливим є дотримання вимог щодо належності, допустимості, достовірності та достатності доказів, своєчасне подання яких забезпечує швидке вирішення справи та задоволення позову про стягнення збитків.

Отже, під час проведеного дослідження:

1) доопрацьовано положення щзодо розподілу обов'язку доказування і подання доказів у справах щуодо стягнення збитків у господарському судочинстві з конкретизацією обов 'язків, покладених на кожну зі сторін спору; 
2) конкретизовано перелік доказів, які можуть бути прийняті господарським судом у справах про стягнення збитків щодо: а) вартості втраченого, пошкодженого або знищеного майна (письмові: правовстановлюючий документ на майно, акт прийому-передачі майна, матеріали інвентаризації, документи бухгалтерського обліку, проєктно-кочторисна документація, фінансова звітність, матеріали аудиту, акт оцінки майна, акт обстеження майна тощо; висновок бухгалтерської, транспортно-товарознавчої, авто-товарознавчої експертизи тощо); б) матеріальної компенсації моральної (немайнової) шкоди (письмові: документи бухгалтерського обліку (фінансова звітність), де зазначається вартість нематеріальних активів; висновок експерта; в) втраченої вигоди (письмові докази, які підтверджують, що доходи могли бути реально одержані);

3) з'ясовано, що використання речових доказів у справах про стягнення збитків не набуло поширення.

Врахування суб'єктами господарювання викладених положень сприятиме прийняттю господарськими судами однакових рішень та надасть можливість суб'єктам господарювання, права яких порушено, стягнути збитки у повному обсязі.

Подальші дослідження щодо доказування та доказів у справах про стягнення збитків доцільно приділити конкретизації кола доказів, які можуть бути подані на підтвердження додаткових витрат, понесених стороною, яка зазнала збитків внаслідок порушення зобов'язання другою стороною. Крім цього, окремого вивчення потребують проблеми застосування електронних доказів та показань свідків під час вирішення спору про стягнення збитків у сфері господарювання, які не були предметом цього дослідження.

1. Господарський процесуальний кодекс України: Закон України від 6 листопада 1991 р. № 1798-XII. Відомості Верховної Ради України. 1992. № 6. Ст. 56. (Із змінами).

2. Господарський кодекс України: Закон України від 16 січня 2003 р. № 436-IV. Відомості Верховної Ради Украӥни. 2003. № 18. Ст. 144. (Із змінами).

3. Цивільний кодекс України: Закон України від 16 січня 2003 р. № 435-IV. Вiдомості Верховної Ради Украӥни. 2003. № 40. Ст. 356. (Із змінами).

4. Про деякі питання практики вирішення спорів, пов'язаних з відшкодуванням шкоди: Роз'яснення Вищого арбітражного суду України від 1 квітня 1994 р. № 02-5/215. Офіиійний веб-портал Верховної Ради України. URL: http://zakon3.rada.gov.ua/laws/show/v_215800-94

5. Хозяйственный кодекс Украины: научно-практический комментарий / под общ. ред. А. Г. Бобковой. Харьков: Издатель ФЛ-П Вапнярчук Н. Н., 2008. 1296 с.

6. Войціховський В. А. Стягнення збитків та інші способи відшкодування майнової шкоди. Судова влада України. URL: https://vl.arbitr.gov.ua/sud5004/pres-centr/news/777307

7. Дегтярев С. Л. Процессуальные аспекты возмещения убытков в гражданском и арбитражном процессе. Убытки и практика их возмещения: сборник статей / отв. ред. М. А. Рожкова. Москва: Статут, 2006. С. 489-521.

8. Зятіна Д. Докази і доказування в господарському процесі: новітня практика Касаційного господарського суду. Підприємниитво, господарство і право. 2019. № 6. С. 83-88. 
9. Теньков С. Як правильно засвідчувати копії документів: помилки судів. LexInform: Юридичні новини України. URL: https://lexinform.com.ua/sudova-praktyka/yak-pravylno-zasvidchuvaty-kopiyi-dokumentiv-pomylky-sudiv

10. Про державну реєстрацію речових прав на нерухоме майно та їх обтяжень: Постанова Кабінету Міністрів України від 25 грудня 2015 р. № 1127. Офіиійний вісник Украӥни. 2016. № 2. Ст. 108.

11. Вимоги щодо складання первинних документів: Лист Мінфіну від 13 червня 2017 p. № 35210-07/23-2135/1/1902. Ліга: Закон. URL: http://search.ligazakon.ua/1_doc2.nsf/link1/ MF17091.html

12. Про затвердження типових форм з обліку та списання основних засобів, що належать установам і організаціям, які утримуються за рахунок державного або місцевих бюджетів, та Інструкції з їх складання: Наказ Державного Комітету статистики України від 2 грудня 1997 р. № 125/70 (втратив чинність 13.09.2016 р.). Офіиійний веб-портал Верховної Ради Украӥни. URL: http://zakon3.rada.gov.ua/laws/show/z0612-97

13. Порядок складання типових форм з обліку та списання основних засобів суб'єктами державного сектору: Наказ Міністерства фінансів України від 13 вересня 2016 р. № 818. Opiиійний веб-портал Верховної Ради України. URL: https://zakon.rada.gov.ua/laws/show/z1336-16

14. Про затвердження Методики оцінки майна: Постанова Кабінету Міністрів України від 10 грудня 2003 р. № 1891. Офіційний вісник України. 2003. № 51. Ст. 2669.

15. Про оцінку майна, майнових прав та професійну оціночну діяльність в Україні: Закон України від 12 липня 2001 р. № 2658-III. Відомості Верховної Ради України. 2001. № 47. Ст. 251.

16. Рішення господарського суду м. Києва від 12 січня 2015 р. у справі № 910/23924/14. Єдиний держсавний реєстр судових рішень. URL: http://www.reyestr.court.gov.ua/ Review/ 42314777

17. Про судову експертизу: Закон України від 25 лютого 1994 р. № 4038-XII. Вiдомості Верховної Ради Украӥни. 1994. № 28. Ст. 232.

18. Про затвердження Інструкції про призначення та проведення судових експертиз та експертних досліджень та Науково-методичних рекомендацій з питань підготовки та призначення судових експертиз та експертних досліджень: Наказ Міністерства юстиції України від 8 жовтня 1998 р. № 53/5. Офіиійний вісник України. 1998. № 46. Ст. 172.

19. Про Довідник з підготовки матеріалів, що направляються на судову експертизу арбітражними судами: Наказ Вищого арбітражного суду України, Міністерства юстиції України від 14 липня 1998 р. № 11/40/5. Офіиійний веб-портал Верховної Ради Украӥни. URL: http://zakon2.rada.gov.ua/laws/show/v0011800-98/print1476604937026407

20. Про судову практику в справах про відшкодування моральної (немайнової) шкоди: Постанова Пленуму Верховного Суду України від 31 березня 1995 р. № 4. Офіційиий вебпортал Верховної Ради Украӥни. URL: http://zakon3.rada.gov.ua/laws/show/v0004700-95

21. Рішення господарського суду м. Києва від 25 листопада 2019 р. у справі № 910/11361/19. Єдиний державний реєстр судових рішень. URL: http://reyestr.court.gov.ua/Review/86335932

22. Рішення господарського суду м. Києва від 11 грудня 2014 р. у справі № 910/18746/14. Єдиний держсавний реєстр судових рімень. URL: http://www.reyestr.court.gov.ua/Review/42203550

23. Рішення господарського суду Рівненської області від 3 липня 2012 р. у справі № 5019/372/12. Єдиний державний реєстр судових рімень. URL: http://www.reyestr.court. gov.ua/Review/48697789

24. Про затвердження Положення (стандарту) бухгалтерського обліку 8 «Нематеріальні активи»: Наказ Міністерства фінансів України від 18 жовтня 1999 р. № 242. Офіиійиний вісник Украӥни. 1999. № 44. Ст. 229.

25. Національне положення (стандарт) бухгалтерського обліку в державному секторі 122 «Нематеріальні активи»: Наказ Міністерства фінансів України від 12 жовтня 2010 р. № 1202. Офіиійний вісник Украӥни. 2010. № 86. Ст. 3067.

26. Про деякі питання практики застосування господарськими судами законодавства про інформацію: Інформаційний лист Вищого господарського суду України від 28 березня 2007 р. № 01-8/184. Вісник господарського судочинства. 2007. № 3. Ст. 46. 
27. Про деякі питання практики застосування господарськими судами законодавства у справах, в яких заявлено вимоги про відшкодування збитків: Оглядовий лист Вищого господарського суду України від 14 січня 2014 р. № 01-06/20/20143. Вісник господарського судочинства. 2014. № 2. Ст. 14.

28. Рішення господарського суду Житомирської області від 5 березня 2019 р. у справі № 906/452/18. Сдиний державний реєстр судових рішень. URL: http://www.reyestr.court.gov.ua/ Review/80365282

29. Рішення господарського суду м. Києва від 28 травня 2019 р. у справі № 910/4238/19. Єдиний державний реєстр судових рішень. URL: http://www.reyestr.court.gov.ua/Review/82006406

30. Господарський процесуальний кодекс України: наук.-практ. комент. (четверте видання, із змінами і допов. станом на 1 серпня 2014 р.) / В. Е.Беляневич. Київ: Юстініан, 2014. 1304 с.

DOI 10.31558/2518-7953.2019.2.13

УДК 346.9:347.233

Ю. О. Серебрякова,

доцент кафедри господарського права Донецького національного університету

імені Василя Стуса, кандидат юридичних наук, доцент

\section{ЗАХИСТ ПРАВА ВЛАСНОСТІ У ГОСПОДАРСЬКОМУ СУДОЧИНСТВІ}

Ключові слова: захист, право власності, господарське судочинство, суб'єкти господарювання, правовстановлюючі документи, спір про право, позовне провадження, окреме провадження, господарський суд.

Захист права власності суб'єктів господарювання є одним із найважливіших завдань господарського судочинства, адже власність $\epsilon$ основою здійснення господарської діяльності. Водночас нині існують серйозні перепони щодо захисту цього права у господарському судочинстві. Зокрема поширеною є судова практика відмови у задоволенні позовів про визнання права власності у разі втрати правовстановлюючих документів, визнання права власності на безхазяйну річ, на об'єкт самочинного будівництва, за набувальною давністю з підстави відсутності спору про право.

Правову основу захисту права власності суб’єктів господарювання складають положення Господарського кодексу України, Господарського процесуального кодексу України (далі - ГПК України) [1] та Цивільного кодексу України (далі ЦК України) [2], однак відповідні положення не враховують специфіку вищевказаних категорій справ. Чинним законодавством передбачена тільки позовна форма розгляду справ у господарському судочинстві, що унеможливлює захист права власності суб'єктів господарювання у зазначених вище випадках. 